\title{
FOSTERING SENIOR SECONDARY STUDENTS' ATTITUDE AND ACHIEVEMENT IN BIOLOGY IN FCT-ABUJA USING FACEBOOK INSTRUCTIONAL STRATEGY
}

\author{
Regina M.O. Samba ${ }^{1}$, Benjamin I. Imoko ${ }^{2}$ and Isa A. A. Muluku ${ }^{3^{*}}$ \\ 1\&2. Department of Science and Mathematics Education, Benue State University, Makurdi; \\ sambaregina2015@gmail.com. \\ 3*. Department of Biology, College of Education, Zuba, FCT Abuja, Nigeria; \\ isaamuluku@gmail.com.
}

\begin{abstract}
The study investigated how Facebook Instructional Strategy could be used to foster Senior Secondary Students' Attitude and Achievement in Biology in FCT-Abuja. A quasiexperimental research design was adopted. The population comprised 12719 senior secondary two biology students. The sample consisted of 247 SSII biology students selected from six government schools in the study area using purposive sampling technique. Data were generated using Germination Achievement Test (GAT) and Students' Attitude to Biology Questionnaire $(S A B Q)$. The GAT and $S A B Q$ were validated and subjected to reliability analysis using KuderRichardson formula $21\left(K-R_{21}\right)$ and Cronbach Alpha formula which yielded coefficients of 0.75 and 0.68 respectively. Six research questions guided the study, while six hypotheses were formulated. Data collected were analyzed using mean and standard deviations to answer the research questions while Analysis of Covariance (ANCOVA) was used to test the hypotheses at 0.05 level of significance. The findings of the study revealed that there is significant difference in the mean achievement score of students taught seed germination using facebook instructional strategy and those taught using the lecture method; there is significant difference in the mean achievement scores of male and female students taught seed germination using facebook instructional strategy. There is no significant difference in the mean attitude ratings of students taught seed germination using facebook instructional strategy and those taught using lecture method; There is no significant difference in the mean attitude ratings of male and female students taught seed germination using facebook instructional strategy. Based on the findings, it was recommended amongst others that biology teachers-trainees should be trained on the use of facebook instructional strategy in teaching biology.
\end{abstract}

KEY WORDS: Facebook instructional strategy, achievement, attitude, seed germination, gender, Biology.

\section{INTRODUCTION}

Science is a key factor in the development of any nation. It is the bedrock of technological careers. Scientific and technological development is dependent on the level of scientific knowledge a nation has (Abungwa, Okene \& Wachanga, 2014). Furthermore the authors observed that the evidence and importance of science in human development are numerous, for instance, it is primarily concerned with solutions to practical problems or finding simplified ways of doing things. Science can be beneficial in making life useful, meaningful and easy for humanity. Despite this importance attached to science, several research reports indicate that students' achievement 
in secondary school science subjects is poor especially Biology (Okoli, 2006; Ofonime, 2007; Samba \& Eriba, 2012; Agogo \& Naakaa 2014).

Biology is a subject that is done by all the science students at the senior secondary school level. Sorajini (2013) opined that Biology as the branch of science that deals with the study of life. It is a fascinating study that ranges from microscopic cellular molecules to the biosphere, encompassing the earth's surface and its living organisms. The knowledge of Biology promotes the understanding of the relationship between man and his environment and the interrelationship between living and non-living things. The understanding of Biology constitutes the basis for other life science such as public health, medicine, agriculture, bio-chemistry, micro Biology, zoology, physiology, botany, anatomy, genetics and ecology (Agogo \&Naakaa, 2014; Ochuba, 2010).

Efe and Efe (2011) maintained that the study of Biology has helped humans to understand the similarities between all forms of life. For example, the genetic code that helps to construct all living organisms is very similar in all life forms. The genetic material is stored in the form of Deoxyribonucleic Acid (DNA) for all plants, animals, bacteria and fungi. By studying the DNA of all these different life forms, biologists have determined that all living creatures are related to each other. By knowledge of Biology, we can understand the species which are endangered and protect them from extinction.

Changes in the natural world and events that unfold around youths and children challenge teachers of Biology to rethink epistemology and pedagogy in Biology classrooms today, as the practice of Biology education like other sciences needs to be proactive and relevant to the students so as to prepare them for life in the present and the future (Ukamala, 2015). The teaching of Biology has been met with a number of challenges. The challenges could be overcome when effective teaching methods such as the electronic-learning strategy are employed. Electronic-learning gives learners the opportunity to expand their knowledge base and develop skills through problem solving and investigation using the internet. Pappas (2015) reported that, online learners are able to gain invaluable experience by doing and actively participating in the learning process, rather than just reading the information presented and then taking a test at the end of the e-learning course. Abdulrahaman, Gambari and Shittu (2014) maintained that the invention of the internet has brought a radical change to how teaching and learning is implemented in today's world of learning. Internet it is a global computer network providing a variety of information and communication facilities, considering of interconnected networks using standard communication protocols. Oghenetega and Igere (2014) pointed out that it is a vast computer network linking smaller computer networks worldwide. It is the transport vehicle for the information stored in files or documents on a computer. It carries together various information and services, such as electronic mail online chat, file transfer, the internet web pages and other documents of the World Wide Web. Examples of internet includes; social media, Skype, WhatsApp, Tweeter, Linked in, Instagram, YouTube, Snapchat, Pinterest, Google plus and Facebook. The incredibly successful social media site, facebook has a billion users so it's a fair guess to say that most students today have a facebook profile (Prescott, 2013). Dolphin (2017) noted that facebook is a social networking website where users can post comments, share photographs and post links to news or other interesting contents on the web, chat lives and watch short form videos. 
Facebook according to Pappas (2015) is the world's largest social networking site. It was created in 2004 by Mark Zuckerberg and was initially designed for college students. Khan (2015), stressed that students probably spend more time on facebook than they do studying or completing homework/assignments. Today, the popularity of the site has made it accessible to anyone who has internet access. Facebook can be operated by creating a personal profile; users can connect with friends from their home town and from all over the world. Besides posting status updates and photos, friends can interact via online chat and private email. You can make your profile either public or private, accept or deny friends, and make friends requests. As a teacher, the question then becomes, how facebook can be utilized maximally in the classroom as teaching/learning strategy? This assertion becomes pertinent when one considers that with the invention of the internet and its everyday accessibility, accessing knowledge is made easier. According to Limayem, Rouis and Esmail (2011), the facebook instructional strategy is a teaching booster to enhance learning and interest of learners towards learning. This therefore stresses the need for practical teaching and learning of Biology using facebook instructional strategy, hopefully to enhance the students' achievement and attitude towards Biology.

On his part, Vikoo (2011) opined that the lecture method is only concerned with verbal presentation of concepts and ideas to the students. Hence it does not promote meaningful learning of Biology since students are not actively involved in the learning process. Ogbeba and Naakaa (2013) defined achievement as the ability to perform a given task successfully at a given time. It is completing of goals set by an individual, organization or nations. Ajewo (2016) noted that despite the relevance of Biology in national development, students' achievement is still poor. Poor achievement in Biology has been accounted for by factors such as poor teaching method (Abidemi, 2014; Adumbu, 2014; Uchendu, 2015; Ajewo, 2016). Jeremi (2017) viewed this ugly trend of high failure rate in Biology as a national disaster. It is blamed on teacher-centered teaching method which is didactic with learners, simply listening, copying notes and taking assignments. This therefore calls on Biology educators to intensify efforts in research in order to proffer solution to this national disaster. According to Uchendu (2015) teachers should improve their teaching methods in order to enhance a better understanding and application of Biology amongst students. This calls for a search for one of the positive ways of improving students' achievement and attitude.

Attitudes can be described as a state of readiness, a tendency to act or react in a certain way. In general, it refers to a learned disposition or tendency on the part of individual to respond positively or negatively to a situation or another person. Agbile (2015) opined that attitude influences how well students adjust and how they behave. Malin and Gulnur (2014) maintained that attitude towards Biology deals with the beliefs, interest; perception and aspiration, practicing habits, persistence and self-concept of students in dealing with Biology. Ahmad and Asghar (2011) said that attitudes play a major role in the understanding of Biology concepts. The enthusiasm with which students enter into any learning activity is determined by their attitude to that particularly activity. Students seem to learn more efficiently those things that appear to interest them. The attitude and result of learning efficiency of male and female students in project-based e-learning such as facebook strategy may be different, hence the issue of male and female achievement in Biology. 
According to Agogo and Naakaa (2014), gender is a socially ascribed attribute that differentiates feminine from masculine. Researchers have shown that difference in academic achievement due to gender has caused a lot of concern to educators, (Kamar \&Foong, 2015; 2014; Hussani, Ahmad \& Asghar, 2015). Students' achievement in Biology with respect to gender has continued to be of interest to researchers (Abidemi, 2014); found that there is a significant difference in the achievement of students and attitude to Biology. This brings about the search for result-oriented methods of teaching Biology that are gender friendly and which potentially can influence achievement and attitude of learners at this level. It is against this background that the researcher is investigating the effects of the usage of facebook on senior secondary students' attitude to and achievement in Biology in FCT-Abuja.

\section{Research Questions}

The following research questions are raised to guide the study:

1. What is the difference in the mean achievement scores of students taught seed germination using facebook instructional strategy and those taught using the lecture method?

2. To what extent is there a difference in the mean achievement scores of male and female students taught seed germination using facebook instructional strategy?

3. What is the difference in the mean attitude rating of students taught seed germination using the facebook instructional strategy and those taught using lecture method?

4. To what extent is there a difference in the mean attitude ratings of male and female students taught seed germination using facebook instructional strategy?

\section{Hypotheses}

The following null hypotheses were formulated to guide the study and were tested at 0.05 level of significance.

1. There is no significant difference in the mean achievement scores of students taught seed germination using facebook instructional strategy and those taught using the lecture method.

2. There is no significant difference in the mean achievement scores of male and female students taught seed germination using facebook instructional strategy.

3. There is no significant difference in the mean attitude ratings of students taught seed germination using facebook instructional strategy and those taught using lecture method.

4. There is no significant difference in the mean attitude ratings of male and female students taught seed germination using facebook instructional strategy.

\section{METHODOLOGY}

The design of this study was quasi-experimental. Specifically, it was a pre-test post-test control group design. The main trust of this experimental design according to Emaikwu (2013) is to establish cause-and-effect. Such a design enables the production of the data to be observed under the control of the researcher in order to investigate cause-effect relationship. The design was also chosen because it is not possible to have a complete randomization of subjects. Therefore, intact classes were used so as not to disrupt the already existing setting in the schools. Emaikwu (2013), Iortimah and Aligba (2011) stated that intact classes should be used only where it is not possible to assign subjects to experimental and control groups randomly. This reason justified its use for the study. The study was carried out in Abuja, the Federal Capital Territory. The choice of this area was based on the fact that less research work has been conducted in this area on the topic. 
Abuja has many institutions of learning. The notable universities include African Institute of Science Technology, Base University, Nigerian Turkish Nile University, University of Abuja, Veritas University, National Open University of Nigeria and Nile University, and FCT College of Education, Zuba, Abuja-FCT. The International Schools include White Plains British School Jabi and American International School of Abuja. The Federal Capital Territory has numerous nursery, primary and secondary schools. The population of the study comprised 12,719 senior secondary school two Biology students in Federal Capital Territory of Abuja (Research and Statistics Unit of Secondary Education Board Abuja 2018). The sample consists of 247 SS 2 Biology students made up of 125 boys and 122 girls in six public senior secondary schools selected for the study. Purposive sampling technique was employed in the selection of the schools which have computers for the study. This is because attention was focused on the schools that fulfill certain criteria necessary for inclusion in the study. Two instruments were constructed for use in this study. The instruments were: Germination Achievement Test (GAT) and Students Attitude to Biology Questionnaire (SABQ). The GAT consists of forty multiple choice questions. One correct response and three detractors were given. The test items were developed by the researcher using WAEC past question papers and Biology textbooks based on the contents to be taught in the lessons. The SABQ was a five point likert type questionnaire consisting of forty items. The 5point Likert Scale of Strongly Agree (SA-5), Agree (A-4), Undecided (U-3), Disagree (D-2) and Strongly Disagree (SD-1). Some of the items are negative while some are positive.

In order to determine the reliabilities of the items of the Germination Achievement Test (GAT) and Students Attitude to Biology Questionnaire (SABQ), the researcher administered the instruments on 40 SS 2 Biology students of Government Secondary School Kwali. The reliabilities co-efficient of the instruments were determined using $\mathrm{K}-\mathrm{R}_{(21)}$ reliability Coefficient for Germination Achievement Test (GAT) and Chrombach alpha for the Students Attitude to Biology Questionnaire (SABQ) It was calculated to be 0.75 and 0.68 respectively. The researcher visited the schools and sought for permission from the principals of the schools. One research assistant was trained in each of the six schools and was used in administering the instruments. The total period that was used for data collection was seven weeks. The first week was allotted for training of the research assistants and six weeks for the actual experiment.

In the first week, a pre-test was administered to all the students in the two groups. At the end of the treatment session, post-tests were administered to the students for the study. The researcher took the following measures to reduce external influences in the course of data collection.

1. Lesson Plan: Lesson plans for experimental and control groups were prepared by the researcher and handed over to the teachers to reduce teachers' effect on the lesson preparation.

2. Hawthorne Effect: Care was made to ensure that students were taught by their own teachers whom they were familiar with and were not told that is an experiment. This enabled the researcher reduce the effect on students' achievement as a result of consciousness of the fact that they were involved in an experiment.

3. Subject Interaction: Subjects in the experimental and control groups belonged to different schools not close to each other. This was to ensure that there was no interaction of subjects across experimental and control groups.

4. Effect of Pre-test on Post test: The period between the pre-test and post-test was 6 weeks. This was assumed to be enough time to prevent the pre-test from affecting the result of the posttest. 
5. Pre-test and Post-test items were the same items but different in arrangement.

6. Only mixed schools were used in the experiment.

Mean scores and standard deviation were used to answer the research questions. Analysis of Covariance (ANCOVA) was used to test the hypotheses at 0.05 level of significance. The choice of ANCOVA is because it was a pre-test post-test design.

\section{RESULTS}

Table 1:Mean Achievement Scores of Students taught Seed Germination using Facebook Instructional Strategy and those taught using the Lecture Method

\begin{tabular}{lllll}
\hline Strategy & & PreGAT & PostGAT & Mean Gain \\
\hline & Mean & 7.3171 & 17.7683 & 10.45 \\
Facebook Strategy & N & 82 & 82 & \\
& Std. Deviation & 2.43370 & 3.40768 & \\
Lecture Method & Mean & 7.2683 & 9.7195 & 2.45 \\
& N & 82 & 82 & \\
Mean difference & Std. Deviation & 3.12319 & 3.27834 & \\
\hline
\end{tabular}

Field Data: 2019

The analysis of data on Table 1 shows the difference in the mean achievement scores of students taught seed germination using facebook instructional strategy and lecture method. The table shows that 82 students were taught seed germination using facebook instructional strategy while 82 students were taught seed germination using lecture method. The table reveals that the mean achievement scores of students taught seed germination using facebook instructional strategy is 7.32 with a standard deviation of 2.43 during pre-test and 17.77 with a standard deviation of 3.41 in post test. The mean achievement scores of students taught seed germination using lecture method is 7.27 with a standard deviation of 3.12 during pre-test and 9.72 with a standard deviation of 3.28 in post test. Table 1 further shows that the mean gains of students that are taught seed germination using facebook instructional strategy is 10.45 and those taught seed germination using lecture method is 2.45 . The difference in the mean gains between the students that are taught seed germination using facebook instructional strategy and lecture method is 8.00 in favour of SSII students that are taught seed germination using facebook instructional strategy.

Table 2: Mean Achievement Scores of Male and Female Students taught Seed Germination using Facebook Instructional Strategy

\begin{tabular}{lllll}
\hline Gender & & PreGAT & PostGAT & Mean Gain \\
\hline \multirow{3}{*}{ Male } & Mean & 6.9706 & 26.4706 & 19.50 \\
& $\mathrm{~N}$ & 34 & 34 & \\
Female & Std. Deviation & 2.81215 & 3.78382 & \\
& Mean & 7.7143 & 29.1837 & 21.47 \\
Mean difference & $\mathrm{N}$ & 49 & 49 & \\
\hline
\end{tabular}

Field Data: 2019 
Table 2 shows the difference in the mean achievement scores of male and female students taught seed germination using facebook instructional strategy. The table shows that 34 male students and 49 female students were taught seed germination using facebook instructional strategy. The table reveals that the mean achievement scores of male students taught biology using facebook instructional strategy is 6.97 with a standard deviation of 2.81 during pre-test and 26.47 with a standard deviation of 3.78 in post test. While the mean achievement scores of female students taught seed germination using facebook instructional strategy is 7.71 with a standard deviation of 2.50 during pre-test and 29.18 with a standard deviation of 5.22 in post test, Table 2 further shows that the mean gain of male students that were taught seed germination using facebook instructional strategy is 19.50 and those of female students taught seed germination using facebook instructional strategy is 21.47. The difference between the mean gains of male and female students taught seed germination using facebook instructional strategy is 1.97 in favour of SSII biology female students.

Table 3:Mean Attitude Rating of Students taught Seed Germination using the Facebook Instructional Strategy and those taught using Lecture Method

\begin{tabular}{lllll}
\hline Strategy & & PreSABQ & PostSABQ & Mean Gain \\
\hline \multirow{2}{*}{ Facebook Strategy } & Mean & 3.3820 & 3.6826 & 0.30 \\
& $\mathrm{~N}$ & 82 & 82 & \\
& Std. Deviation & .48406 & .37667 & \\
Lecture Method & Mean & 3.4213 & 3.6134 & 0.19 \\
& $\mathrm{~N}$ & 82 & 82 & \\
Mean difference & Std. Deviation & .53705 & .52450 & \\
\hline
\end{tabular}

Field Data: 2019

The analysis of data on Table 3 shows the difference in the mean attitude rating of students taught seed germination using facebook instructional strategy and lecture method. The table shows that 82 students were taught seed germination using facebook instructional strategy while 82 students were taught biology using lecture method. The table reveals that the mean attitude rating of students taught seed germination using facebook instructional strategy is 3.38 with a standard deviation of 0.48 during pre-test and 3.68 with a standard deviation of 0.38 in post test. While the mean attitude rating of students taught seed germination using lecture method is 3.42 with a standard deviation of 0.54 during pre-test and 3.61 with a standard deviation of 0.52 in post test, Table 3 further shows that the mean gain of students that are taught seed germination using facebook instructional strategy is 0.30 and those taught seed germination using lecture method is 0.19 . The difference in the mean gain between the students that weretaught seed germination using facebook instructional strategy and lecture method is 0.11 in favour of SSII students that were taught seed germination using facebook instructional strategy. 
Table 4:Mean Attitude Ratings of Male and Female Students taught Seed Germination using Facebook Instructional Strategy

\begin{tabular}{lllll}
\hline Gender & & PreSABQ & PostSABQ & Mean Gain \\
\hline \multirow{3}{*}{ Male } & Mean & 3.4081 & 3.7949 & 0.39 \\
& $\mathrm{~N}$ & 34 & 34 & \\
Female & Std. Deviation & .42697 & .35531 & \\
& Mean & 3.4607 & 3.9250 & 0.46 \\
Mean difference & $\mathrm{N}$ & 49 & 49 & \\
\hline
\end{tabular}

Field Data: 2019

The analysis of data on Table 4 shows the difference in the mean attitude ratings of male and female students taught seed germination using facebook instructional strategy. The table shows that 34 male students and 49 female students were taught biology using facebook instructional strategy. The table reveals that the mean attitude ratings of male students taught seed germination using facebook instructional strategy is 3.41 with a standard deviation of 0.43 during pre-test and 3.79 with a standard deviation of 0.36 in post test. The mean attitude ratings of female students taught seed germination using facebook instructional strategy is 3.46 with a standard deviation of 0.55 during pre-test and 3.93 with a standard deviation of 0.39 in post test. Table 4 further shows that the mean gain of male students that are taught seed germination using facebook instructional strategy is 0.39 and that for female students taught biology using facebook instructional strategy is 0.46. The difference between the mean gains of male and female students taught seed germination using facebook instructional strategy is 0.07 in favour of SSII female students.

Table 5: Comparisons of Mean Achievement Scores of Students taught Seed Germination using Facebook Instructional Strategy and those taught using the Lecture Method

\begin{tabular}{llll}
\hline (I) Strategy & (J) Strategy & Mean Difference (I-Std. Error & Sig. $^{\text {b }}$
\end{tabular}

\begin{tabular}{lllll}
\hline $\begin{array}{l}\text { Facebook } \\
\text { Strategy }\end{array}$ & Lecture Method & $8.049^{*}$ & .613 & .000 \\
\hline
\end{tabular}

Field Data: 2019

Table 5 shows the bivariate comparisons of the methods of teaching seed germination and its effect on the mean achievement scores of students at $\mathrm{P}=0.000<0.05$ for facebook instructional strategy and lecture method. The null hypothesis is therefore rejected. This implies that there is statistically significant difference in the mean achievement scores of students taught seed germination using facebook instructional strategy and those taught using the lecture method. 
Table 6: ANCOVA of Mean Achievement Scores of Male and Female Students taught Seed Germination using facebook Strategy

\begin{tabular}{lllllll}
\hline Source & $\begin{array}{l}\text { Type III Sumdf } \\
\text { of Squares }\end{array}$ & & Mean Square F & Sig. & $\begin{array}{l}\text { Partial } \\
\text { Squared }\end{array}$ & Eta \\
\hline Corrected Model 210.019a & 2 & 105.010 & 11.355 & .000 & .223 \\
Intercept & 2953.868 & 1 & 2953.868 & 319.412 & .000 & .802 \\
PreGAT & 21.767 & 1 & 21.767 & 2.354 & .129 & .029 \\
Gender & 187.485 & 1 & 187.485 & 20.273 & .000 & .204 \\
Error & 730.578 & 79 & 20.273 & & & \\
Total & 26829.000 & 82 & & & & \\
Corrected Total & 940.598 & 81 & & & & \\
\hline
\end{tabular}

a. R Squared $=.223$ (Adjusted R Squared $=.204$ ) Field Data: 2019

Table 6 reveals that $F(1,81)=6.113 ; p=0.000<0.05$. Thus, the null hypothesis is therefore rejected. This implies that there is significant difference in the mean achievement scores of male and female students taught seed germination using facebook instructional strategy. Thus, it can be concluded that based on evidence from data analysis, there is a significant difference in the mean achievement scores of male and female students taught seed germination using facebook instructional strategy. The partial Eta square of 0.204 was obtained for the gender meaning that only $20.4 \%$ of the biology students' achievement can be accounted for byfacebook instructional strategy.

Table 7:Comparison of Mean Attitude Ratings of Students taught Seed Germination using Facebook Instructional Strategy and those taught using Lecture Method

\begin{tabular}{lllll}
\hline (I) Strategy & (J) Strategy & Mean Difference (I-J) & Std. Error Sig. ${ }^{\text {b }}$ \\
\hline Facebook Strategy & Lecture Method & .067 & .068 & .319 \\
\hline
\end{tabular}

Field Data: 2019

Table 7 shows the bivariate comparisons of mean attitude ratings of students taught seed germination using facebook instructional strategy and those taught using lecture method; it indicates a $\mathrm{P}=0.319>0.05$ for facebook instructional strategy and lecture method. The null hypothesis is therefore not rejected. This implies that there is no significant difference in the mean attitude ratings of students taught seed germination using facebook instructional strategy and those taught using lecture method. 
Table 8: ANCOVA of Mean Attitude Ratings of Male and Female Students taught Seed Germination using Facebook Instructional Strategy.

\begin{tabular}{lllllll}
\hline Source & $\begin{array}{l}\text { Type III Sum ofdf } \\
\text { Squares }\end{array}$ & Mean Square & F & Sig. & $\begin{array}{l}\text { Partial Eta } \\
\text { Squared }\end{array}$ \\
\hline Corrected Model & $.340^{\mathrm{a}}$ & 2 & .170 & 1.189 & .310 & .029 \\
Intercept & 25.944 & 1 & 25.944 & 181.491 & .000 & .694 \\
PreSABQ & $1.997 \mathrm{E}-005$ & 1 & $1.997 \mathrm{E}-005$ & .000 & .991 & .000 \\
Gender & .339 & 1 & .339 & 2.374 & .127 & .029 \\
Error & 11.436 & 80 & .143 & & & \\
Total & 1255.943 & 83 & & & & \\
Corrected Total & 11.776 & 82 & & & & \\
\hline
\end{tabular}

a. R Squared $=.029$ (Adjusted R Squared $=.005$ ) Field Data: 2019

Table 8 reveals that $F(1,82)=2.374 ; p=0.127>0.05$. Thus, the null hypothesis is therefore not rejected. This implies that there is no significant difference in the mean attitude ratings of male and female students taught seed germination using facebook instructional strategy. Thus, it can be concluded that based on evidence from data analysis there is no significant difference in the mean attitude ratings of male and female students taught biology using facebook instructional strategy. The partial Eta square of 0.029 was obtained for the gender meaning that only $2.9 \%$ of the biology students' attitude ratings can be attributed to facebook instructional strategy.

\section{DISCUSSION OF FINDINGS}

The study examined the effectiveness of the usage of facebook on senior secondary students' attitude and achievement in seed germination. Since the population for the study consists of both male and female students, gender was incorporated as a moderating variable for comparison. Discussions of findings is based and tailored along the variables in the study as guided by the results of research questions and hypotheses.

The findings also revealed that there is significant difference in the mean achievement scores of students taught seed germination using facebook instructional strategy and those taught using the lecture method. This means that biology could be better taught using facebook instructional strategy than lecture method. The findings agree with that of Ogbonaya (2015) that students taught with facebook achieved higher than those taught using lecture method. It should be borne in mind that facebook instructional strategy should not be excessively used to the detriment of other strategy. It is in the light of this fact that the findings agree with that of Esmail, Moez and Rouis (2011) that an extensive use of facebook by students with extraverted personalities leads to poor academic performance. However, students who are more self-regulated more effectively control their presence and interaction on this platform. Yet students' cognitive absorption with facebook is only regulated by their self-control and their personality traits, which determines how much time they spend on facebook. Multitasking skills moderate the effect of cognitive absorption on academic achievement but they do not impede the time spent, frequency or nature of use or their effect on academic results. The findings on the use of facebook instructional strategy and gender revealed that there is significant difference in the mean achievement scores of male and female 
students taught biology using facebook instructional strategy. This implies that the use of facebook instructional strategy is not gender friendly.

While finding on the interaction effect of method and gender revealed that there is significant interaction effect of method and gender on the mean achievement of students in seed germination. This means that the use of facebook, and lecture method appeal to the male and female biology students differently with a resultant difference in their achievement in biology. The findings agree with that of Adeyemi and Ajibade (2011) that there is a significant interaction effect of treatment and gender on students' achievement in social studies.

The finding on the use of facebook instructional strategy and gender also revealed that there is no significant difference in the mean attitude ratings of male and female students taught biology using facebook instructional strategy. The findings agree with that of Ahmad and Asghar (2011) that no significant difference between girls and boys in attitude towards Biology. The findings also agree with that of Iliyasu and Yahya (2015) that attitudes of male and female students were significantly insignificant. Facebook is one of the most famous social networking websites which has become a part of the daily routine for most college students, hence its application in this study. This has provided answers to the question amongst researchers whether students' use of this networking site influences their academic outcomes. Cain and Policastri (2011) defined facebook as a free social networking web platform that promotes and facilitates interaction between friends, family and colleagues. Facebook was founded in 2004 by Mark Zuckerberg and several Harvard University classmates.

The finding on the interaction effect of method and gender revealed that there is no significant interaction effect of method and gender on the mean attitude ratings of students towards biology. Abidemi (2014) claimed that attitude of students to Biology or germination determined their participation level in the subject. The author further emphasized that attitude of students towards Biology or germination plays a crucial role in the teaching and learning process of biology is a production of many factors. It is determined by Biology teachers, teaching method and attitude, school environmental factors, home influences, societal and peer influence. Therefore the adoption of these instructional strategy in order to arouse a favourable attitude among students towards biology. An effective teaching method is expected to raise students' achievement scores in the subject and retain what is learnt in the class.

The findings of this study were observed to have obvious educational implication. The use of facebook instructional strategy has been found to influence students' attitude and achievement in biology. More time is therefore required on the normal school time-table for effective implementation of the facebook instructional strategy.

\section{CONCLUSION}

Based on the results obtained in the study, it was concluded that using facebook instructional strategy enhanced students' achievement and attitude in biology. The findings of the study also proved that both male and female students benefited from the facebook instructional strategy which has the potential of improving their achievement in biology. 


\section{Recommendations}

Based on the findings of the study, the following recommendations were made:

1. Biology teacher-trainees should be trained on the use of facebook instructional strategy in teaching biology.

2. Teachers should actively involve male and female students in learning activities to avoid gender stereotyping so as to help create equal educational opportunities for both male and female learners.

3. National Education Research and Development Council (NERDC) and other relevant governmental agencies are enjoined to sponsor further researches to determine the efficacy of the facebook strategy in other aspects of biology on a broader base.

4. Curriculum develops and planners should adopt the facebook instructional strategy and create more time for teaching of biology since the usual allotted time is inadequate for the effective implementation of facebook strategy in instructional delivery.

\section{References}

Abdulrahaman, A. Gambari, O. \& Shittu, E. (2014). What the internet has done to mankind. Retrieved on $4^{\text {th }}$ April 2018 from https://www.internet/stmnet/murphyllc/c/le4html

Abungwu, E. O. Okene, I.O. \& Wachanga, W.S. (2014). Effects of science process skills teaching strategy on boys and girls achievement in chemistry in Nyando district, Kenya. Journal of Education and Practices, 5(15), 42-50.

Adeyemi, B.A. \& Ajibade, Y.A. (2011).The comparative effects of simulation games and brainstorming instructional strategy on junior secondary school students' achievement in social studies in Nigeria. African Research Review, 5(20), 64-80.

Adumbu, K. (2014). Difficult topics in Biology. Journal of Scientific Literacy, 3 94), 73-87.

Agbile, T. (2015).The attitude of students towards learning science. International Journal of Education, 23 (9), 783-796.

Agogo, P.O. \&Naakaa, D.A. (2014).Effects of 5Es constructivist instructional strategy on students' interest in senior secondary genetics in Gwer local Government area of Benue State, Nigeria. Global Journal of Environmental Science and Technology, 1 (2), 15-19.

Ahmad, A.I. \& Asghars, S. (2011). Attitude towards Biology and its effects on students' achievement. American-Eurasian Journal of Scientific Research, 5 (5), 213-224.

Cain, J., \& Policastri, A. (2011).Using facebook as an informal learning environment. American Journal of Pharmaceutical Education, 75(10), 207-2016.

Dolphin, S. (2017). Using facebook to teach Mathematics to high school students. Journal of Applied Mathematics, 3(2), 33-42.

Efe, H.A. \& Efe, R. (2011). Evaluating the effect of computer simulations on secondary Biology instruction: An application of Bloom's taxonomy Scientific Research and Essays 6(10), 3137-2146.

Emaikwu, S.O. (2013). Fundamentals of educational research methods and statistics. Makurdi: Selfers Academic Press.

Esmail, A., Moez, O.L. \& Rouis, A. (2011). Impact of facebook usage on students' academic achievement: roles of self-regulation and trust. Educational Psychology 41(3) 113-129.

Hussani, O. Kamar, Z. \& Foong, E. (2015). Gender stereotyping and its effect on students achievement and attitude in Biology. Educational Journal of Research, 9 (3), 37-49.

Iliasu, A. \& Yahaya, A.I. (2015).The attitude of Kebbi State secondary school students towards Biology as a school subject. Journal of Research in Science Teaching, 3(2), 321-335. 
Iortimah, C.G. \& Aligba, S.O. (2011).Improving students' attitude towards mathematics. Benue Journal of Mathematics and Mathematics education, 1(2), 12-23.

Jeremi, K. (2017). Effects of seed position and soil nutrient on seed germination and seedling growth in Peucedanum Oreoselinum.Scientific Reports, 7(1), 1957-1969.

Kamar, T. \& Foong, L.A. (2015). Influence of students' interest and gender on their achievement in secondary school Biology in Philadelphia. Journal of Educational Research, 101(2) 72 89.

Khan, L. (2015).The importance of facebook in our day-to-day communication.Retrieved on $5^{\text {th }}$ April, 2018 from https://research.Fb.com>the-facebook.

Limayem, M., Rouis, S. \& Esmail, S. (2011). Impact of facebook usage on students' academic achievement: Roles of self-regulation and trust. Electronic Journal of Research in Educational Psychology, 9 (3), 936-994.

Malin, O. \& Gulnur, M. (2014). The effect of students' attitude and achievement in Biology.Journal of Scientific Literacy, 7 (2), 99-109.

Ochuba, L. (2010). Comparison of the effect of environment on urban and rural students achievement and interest in Biology.Unpublished PhD thesis.Zaria, Ahmadu Bello University.

Ofonime, F.N. (2007). Effect of constructivist-based instructional model on senior secondary students' achievement in Biology.Proceedings of the $50^{\text {th }}$ annual conference of the Science Teachers Association of Nigeria 98-101.

Ogbeba, J. \& Naakaa, D.A. (2013).Towards improving students' achievement in senior secondary genetics by the use of constructivist-based instructional model.Asian Academic Research Journal of Science and Humanities, 1 (17), 139-151.

Oghenetega, I. \& Igere, M.A. (2014).Impact of internet on academic performance of students in tertiary institutions in Nigeria. Journal of Information and Knowledge Management, 5(2), 47-57.

Okoli, J.N. (2006). Effects of investigative laboratory approach and expository method on acquisition of science process skills by Biology students of different levels of scientific literacy. Journal of Science Teachers Association of Nigeria, 41 (1\&2), 79-88.

Pappas, C. (2015). Project-based learning in e-learning: What e-learning professionals should know.Retrieved on $3^{\text {rd }}$ October 2017 fromwww.elearning industry.com/project.

Prescott, A. (2013). The advantages and disadvantages of facebook to students. Retrieved on $4^{\text {th }}$ April 2018 from https://m.facebook.com>carreeradvantage-disadvantages.

Sorajini, T.R. (2013). Modern Biology for senior secondary schools. Onitsha: African First Publishers Ltd.

Ukamala, C.O. (2015). Teaching types of variation to senior secondary school class 3 students using activity based method. Science Teachers Association of Nigeria (STAN) Biology Panel Series, 142-146.

Vikoo, B. (2011). Effects of conventional and cooperative learning strategy on the academic performance of senior secondary school students. Journal of Technology and Education in Nigeria, 16(2), 56-69. 